Dr. sc. MARTIN PREVIŠIĆ, docent

Filozofski fakultet Sveučilišta u Zagrebu

Zagreb, Republika Hrvatska

martinprevisic@gmail.com

IVAN MLINARIĆ, mag. hist.

Zagreb, Republika Hrvatska

ivanmlinaric99@gmail.com

originalan naučni rad

UDK: 351.746.1(497.5)"1989/1991"

796.332:32(497.5)"1989/1991"

primljeno: 1. septembar 2019.

prihvaćeno: 20. novembar 2019.

https://doi.org/10.29362/ist20veka.2020.1.pre.163-184

\title{
SLUŽBA DRŽAVNE SIGURNOSTI HRVATSKE PROTIV NOGOMETNIH NAVIJAČA 1989-1991.
}

APSTRAKT: Tijekom 1980-ih u Jugoslaviji dolazi do ekspanzije navijačkih skupina. Uslijed opće krize zemlje navijači u Jugoslaviji, kao i njihove aktivnosti, postajale su sve intenzivnijim predmetom interesa jugoslavenske tajne policije. Ovaj rad analizira aktivnosti četiri najveće navijačke skupine u tadašnjoj Socijalističkoj Republici Hrvatskoj (Bad Blue Boys, Torcida, Armada i Kohorta) u razdoblju od 1989. do 1991. godine na osnovu arhivskog materijala Službe državne sigurnosti SR Hrvatske. Rad analizira raznorazne aspekte nadgledanja $i$ shvaćanja pojave i djelovanja navijačkih skupina od strane tajne policije, a poseban naglasak stavljen je na pojavu nacionalizma među njima u kontekstu istovjetnih gibanja u zemlji. Prezentacijom ovih aspekata u radu, rad nastoji doprinijeti historiografskoj analizi uzroka, odnosno atmosfere raspada Jugoslavije.

KLJUČNE RIJEČI: Jugoslavija, Dinamo, Hajduk, Služba državne sigurnosti, navijači, Hrvatska

\section{Uvod}

Smrt Josipa Broza Tita 1980. godine označila je prekretnicu u povijesti socijalističke Jugoslavije i početak krize koja će se odmicanjem desetljeća sve više zaoštravati. ${ }^{1}$ Brojna pitanja od političkog i društvenog značaja bit će otvarana

\footnotetext{
${ }^{1}$ Ovaj rad je nastao u suautorstvu, na temelju ranije suradnje tijekom izrade diplomskog rada Ivana Mlinarića pod naslovom „Politika i navijači - Navijačke skupine u SR Hrvatskoj u izvještajima Službe državne sigurnosti u vrijeme raspada Jugoslavije“, koji je obranjen u rujnu 2018. godine na Filozofskom fakultetu u Zagrebu, pod mentorstvom Martina Previšića. U svom radu Ivan Mlinarić detaljno je analizirao ovu problematiku, s posebnom analizom ustroja, funkcioniranja i infiltracije SDS-a u navijačke skupine u SR Hrvatskoj. Ovaj članak predstavlja svojevrsnu sintezu prezentiranih zaključaka, ali istovremeno, za razliku od ranijeg rada, fokusira se na značaj i pojavu nacionalizma na stadionima i djelovanju i postavljanju SDS-a prema njima. Isto tako, u radu se prezentiraju
} 
i od strane partijskih rukovodstava i izvan partijskog kruga. Od samoga početka desetljeća nizale su se krize za koje je kolektivno partijsko rukovodstvo nalazilo sve manje učinkovitih rješenja: od krupnih problema u gospodarstvu, do međunacionalnih trvenja, odnosa u federaciji, kao i odnosa pokrajina - centar (u Srbiji). Osim toga, tijekom ovog desetljeća svjedočimo otvaranju raznih kontroverznih tema iz povijesti zemlje, kao i pokušaju redogmatizacije (Bijela knjiga) iz partijskih centara. Sve veća nemoć rukovodstva, i saveznog i republičkih, slabila je snagu Saveza komunista Jugoslavije, kao i ideologiju jugoslavenskog komunizma. U takvim uvjetima, republička rukovodstva, osnažena decentralizacijom, procesom koji je kao temeljna orijentacija partije počeo nakon 1948. godine, a dobio snažan zamah tijekom 1960-ih, sve su više nastojala zastupati vlastite partikularne poglede na budućnost zemlje i njezin ustroj. Kriza je dodatno zaoštrena krajem desetljeća kada je tadašnje rukovodstvo Saveza komunista Srbije konstituiralo politiku koja je išla za promjenom odnosa $u$ federaciji, odnosa na relaciji pokrajina - centar, ali i de facto odbacivanjem načela postavljenih Ustavom 1974. godine. Paralelno sa slabljenjem jugoslavenske varijacije komunizma, iako unutar partijskog sistema, kriza se produbljuje afirmiranjem nacionalističkih koncepcija koje su na koncu Jugoslaviju uvele u zadnju fazu dezintegracije i raspada zemlje. ${ }^{2}$

U tom kontekstu, ovaj rad trebao bi doprinijeti proučavanju procesa raspada Jugoslavije krajem 1980-ih godina te odnosu i utjecaju političkih gibanja na društvo, u ovom slučaju na navijače nogometnih klubova. ${ }^{3}$ Naime, još od 1945. godine, kad su jugoslavenski komunisti preuzeli vlast, posebnu pažnju posvetili su afirmiranju sporta u skladu s tadašnjim staljinističkim vizijama uloge sporta u društvu. U tom se kontekstu našao i nogomet. Kako je u Kraljevini Jugoslaviji postojala vrlo razvijena kultura nogometa, i nakon 1945. godine nova vlast išla je za time da se obnovi djelovanje klubova, ali sada u novom ruhu. Osim toga što je većinu klubova percipirala kao „buržoaske“, Partija je u tom razdoblju nastojala izbjeći oživljavanje onih koji su imali razne oblike suradnje s okupator-

novi dokumenti SDS-a, ali i novi radovi (o odnosu nacionalizma i nogometa) o ovoj temi, koji značajno utječu na ovu historiografsku debatu i njenu daljnju razradu.

${ }^{2}$ Više vidi u: Josip Glaurdić, Vrijeme Europe - Zapadne sile i raspad Jugoslavije (Zagreb: MateZŠEM, 2011); Dušan Bilandžić, Propast Jugoslavije i stvaranje moderne Hrvatske (Zagreb: AGM, 2001); Kosta Nikolić, Jugoslavija, poslednji dani (1989-1992) - Svi Srbi u jednoj državi (Beograd: Službeni glasnik, 2018).

${ }^{3}$ U zadnjem desetljeću pojavljuje se pojačan interes za „sportske“ i nogometne teme u historiografijama (ali i ostalim disciplinama) bivše Jugoslavije. Za ovu temu posebno je važan u 2019. godini objavljen prijevod studije Richarda Millsa, Nogomet i politika u Jugoslaviji: sport, nacionalizam i država (Zagreb: Profil, 2019). Original je objavljen 2018. godine na engleskom jezi$\mathrm{ku}$ The politics of football in Yugoslavia - Sport, Nationalism and the State (London-New York: Tauris, 2018). Ova studija daje vrlo istančanu analizu odnosa nogometa i države, posebno u socijalističkoj Jugoslaviji, ali i pojave i značaja nacionalizma na stadionima i klubovima. Zbornik Dario Brentin et all. Sport in Socialist Yugoslavia (London: Routledge, 2019) također daje nekoliko radova koji problematiziraju ulogu i odnos sporta (nogometa) i države. Godine 2019. objavljena je knjiga Davora Kovačića, Nogomet u doba Cara, Kralja, Poglavnika i Maršala (Zagreb; HIP-AGM, 2019) koja tematizira razvoj i afirmaciju nogometa kao igre na prostoru Hrvatske tijekom 20. stoljeća. Brojni drugi povjesničari u svojim radovima analiziraju nogomet u raznim aspektima i kontekstima poput Stipice Grgića, Hrvoja Klasića, Dejana Zeca, i dr. 
skim vlastima, provodili rasističke politike, te koji su zbog toga označeni kao „kolaborantski“. U tu skupinu, primjerice, spadali su klubovi poput BSK-a iz Beograda te Građanskog iz Zagreba, a u jakim republičkim centrima osnivaju se novi klubovi koji često preuzimaju infrastrukturu starih. Iz tih razloga, a i zbog djelomičnog kopiranja sovjetskih modela, nastajali su novi klubovi poput Dinama iz Zagreba i Crvene zvezde iz Beograda, koji su trebali najaviti novo komunističko razdoblje, ali i nastaviti tradiciju nogometne igre na prostorima Jugoslavije. Najbolji primjer kluba ustrojenog po sovjetskom modelu bio je, dakako, Partizan, odnosno „Jugoslovensko sportsko društvo Partizan“, koji je osnovala JNA po uzoru na moskovski CSKA, klub Crvene Armije. Upravo će FK Partizan dobiti tu čast i postati prvi klub koji je 1946. otišao na turneju po Sovjetskom Savezu. ${ }^{4}$

U tim prvim godinama Titove Jugoslavije komunistima je nogomet bio izuzetno važno propagandno sredstvo, sredstvo integracije i iskazivanja ,bratstva i jedinstva“, dok će u procesu raspada Jugoslavije biti upravo jedan od faktora destabilizacije i dezintegracije zemlje. Još je za vrijeme trajanja rata antifašistička momčad Hajduka, osnovana na Visu u svibnju 1944., dobila misiju glancanja ugleda Titovih komunista i njegove vizije Jugoslavije, odigravši niz utakmica u Italiji, na Visu i Malti, a u ožujku 1945. zaputila se i na turneju po Bliskom istoku. ${ }^{5}$ Već u rujnu 1945. u Beogradu je održano nogometno natjecanje koje se smatra pretečom jugoslavenskog prvenstva, a u kojem su sudjelovale momčadi federalnih republika, te momčadi Vojvodine i JNA. Pobjednik natjecanja bila je srbijanska reprezentacija, a prilikom predaje pehara Sovjetske antifašističke mladeži predstavnik Fiskulturnog odbora Jugoslavije Radivoje Marković rekao je sljedeće: „Snažite bratstvo i jedinstvo naših naroda, čuvajte tu najveću tekovinu naše narodno-oslobodilačke borbe, jer jedino pod ovim uslovima, u narodnoj zajednici pod vodstvom našeg voljenog Maršala Tita postoje mogućnosti za svestran razvoj našeg malog fiskulturnog pokreta“، 6

Koliko je toga Jugoslavija polagala u očuvanje bratstva i jedinstva kroz nogomet te zazirala od ,klubašenja“, pojma koji je u suštini podrazumijevao strah od raspirivanja međunacionalne mržnje, svjedoči i ona crtica da je, prema Vladimiru Dedijeru, Tito prestao odlaziti na utakmice jer nije htio da ga se dovodi u vezu s jednim od klubova, pa eventualno i s time da navija za Partizan. ${ }^{7}$

Pojam „klubašenja“ često će se spominjati i u dokumentima Službe državne sigurnosti Republičkog sekretarijata unutrašnjih poslova Socijalističke Republike Hrvatske (dalje: SDS RSUP SRH) potkraj 1980-ih. Taj pojam je u fokus Partije došao još 1950. godine, kad je osnovana „Torcida“, povodom u-

\footnotetext{
${ }^{4}$ R. Mills, Nogomet i politika u Jugoslaviji: sport, nacionalizam i država (Zagreb: Profil, 2019), 78-89; Никола Мијатов, „Спорт у служби социјализма: југословенско искуство 19451953“ (Докторска дисертација, Универзитет у Београду. Филозофски факултет, Одељење за историју, 2019), 225-236; D. Kovačić, n. d., 160-161.

${ }^{5}$ Više vidi u: Mladen Cukrov, „Šezdeset pet godina obnove Hajduka na otoku Visu“, Kulturna baština, br. 9, (2009), 23-42; Ivan Mlinarić, „Naletjeli smo na mali povijesni ekskluziv; Hajduk je 1980. htio da se Poljud nazove po Titu“, www.telegram.hr, 26. 11. 2017, pristupljeno 19. 8. 2019.

${ }^{6}$ R. Mills, $n . d ., 88$.

${ }^{7}$ Isto, 124.
} 
takmice koju je Hajduk 29. listopada u Splitu igrao protiv Crvene zvezde. Ta za jugoslavenske vlasti prilično nepoznata pojava bila je inspirirana brazilskom „Torcidom“, navijačima koji su obilježili Svjetsko prvenstvo u Brazilu 1950, a osnivači grupe bili su skupina Dalmatinaca iz Zagreba koji su dan ranije vlakovima krenuli pristizati u Split. Hajduk je pobjedom osvojio naslov prvaka, a „Torcida“ je tijekom utakmice gromoglasno i bučno navijala, stvarala pritisak na suce te kod drugog gola utrčala u teren. Samo koji dan kasnije u partijskom glasilu Borbi izašao je članak „Tako ne treba navijati”, što je ujedno bio znak da slijedi obračun s osnivačima i organizatorima putovanja. Velik dio njih potjecao je upravo iz partijskih i republičkih struktura pa su neki dobili partijske ukore, neki su izbačeni iz Partije, a jedna je osoba zaradila kaznu zatvora od tri godine, koja je kasnije smanjena na tri mjeseca. ${ }^{8}$

U narednim desetljećima razvijat će se specifična navijačka kultura vezana uz klubove koja se danas u historiografiji, ali i drugim granama, ponajviše sociologiji, tumači na razne načine. Kako ovaj rad analizira praćenje navijačkih skupina od strane SDS-a, najviše onih u Hrvatskoj krajem 1980-ih, odnosno sve veću pojavu nacionalizma na stadionima, treba naglasiti da su i do Titove smrti i početka jugoslavenske krize postojale slične pojave, premda više sporadične i neorganizirane, te u svakom slučaju ne masovnog karaktera kao one kasnije. ${ }^{9}$ Politička, pa i gospodarska klima koje su tada prevladavale, teške kazne koje su mogle sustići počinitelje eventualnih nacionalističkih ispada, kao i činjenica da moderne navijačke skupine još nisu postojale, bili su preduvjet toga. Pa, ipak, ono gdje je tinjao sukob koji je imao prizvuk međunacionalnih trvenja, jest u odnosima republičkih sportskih saveza sa saveznim središtem u Beogradu, a što je bila samo preslika odnosa po pitanju decentralizacije i centralizacije u Jugoslaviji, pitanja prisutnog gotovo pa cijelo vrijeme trajanja obje Jugoslavije. Posebno bitan odnos u tom smislu bio je onaj Zagreba i Beograda. Kad je 1950. Komunistička partija Hrvatske počela istraživati „negativne pojave u sportu“, u jednom je od izvještaja pisalo: „Sve negativne pojave u sportu, pogrešni zaključci i ostali nedostaci koriste se od strane šovinističkih elemenata za raspirivanje nacionalne netrpeljivosti. Sve se to na neki način usmjeruje u vidu borbe Zagreb-Beograd, tj. obrane hrvatskog sporta, naročito nogometa, od hegemonističkih nastojanja Beograda. Sve te nepravilnosti, naročito one počinjene od strane centralnih saveza, tumače se kao njihovo nastojanje na slabljenju hrvatskog sporta. U sportskoj javnosti diskutira se o tim greškama i stvara se javno mnijenje, jasno pod utjecajem neprijatelja, da je za sve kriv Beograd.“10

U kolektivnom sjećanju mnogih bivših djelatnika klubova, igrača, pa i navijača iz Hrvatske, pogotovo onih vezanih uz Dinamo, krivac za njihove vlastite neuspjehe često se krio upravo u Beogradu.

\footnotetext{
${ }^{8}$ Više o osnivanju „Torcide“ vidi u: Dražen Lalić, Torcida: pogled iznutra, 2. izd., (Zagreb: Profil multimedija, 2011), 80-86; Isti, Nogomet i politika: povijest $i$ suvremenost međuodnosa u Hrvatskoj (Zaprešić: Fraktura, 2018), 142-148.

${ }^{9}$ R. Mills, $n . d ., 115-166 ;$ Н. Мијатов, „Спорт у служби социјализма““, 402-412.

${ }^{10}$ R. Mills, $n . d ., 99$.
} 


\section{Osnivanje navijačkih skupina i pojava „stadionskog nacionalizma“}

Kao što je rečeno, jugoslavenska kriza i njeni razni efekti kulminirali su u 1980-im godinama, no za ovaj je rad važnije fokusirati se na pogoršavanje međunacionalnih odnosa, odnosno na porast nacionalizma, u ovom slučaju onoga na nogometnim stadionima. Sporadični nacionalistički ispadi bili su prisutni i ranije, ali nikada u organiziranim, masovnim i kontinuiranim oblicima, a ponajmanje kao fenomen koji se $\mathrm{u}$ isto vrijeme i sličnim intenzitetom pojavljivao na stadionima diljem Jugoslavije. To ne znači da su takve pojave bile sinkronizirane i istovremene u Zagrebu, Beogradu, Titogradu, Sarajevu, Mostaru, Skopju i Prištini, ali kako će desetljeće odmicati one će biti sve češće i sličnije, i u naravi i u sadržaju. Naravno, jedna sličnost je uočljiva, a to je organiziranje navijačkih skupina diljem Jugoslavije sredinom desetljeća.

Vođeni primjerom engleskih navijačkih skupina, koje nastaju tijekom 1960-ih godina i ističu se, osim po bučnom navijanju bez previše navijačkih obilježja, tzv. sjevernjačkom stilu navijanja, svjesnim i namjernim pravljenjem nereda, odnosno fenomenom huliganizma, u Jugoslaviji 1980-ih nastaju brojne navijačke skupine. Prva takva bila je „Torcida“, ponovo osnovana 1980. godine, na tradiciji stare „Torcide“. Ova grupa će u narednim godinama postati daleko najpopularnija omladinska organizacija u Dalmaciji. Upravo je iz njenih redova potekla ideja ponajprije za ime navijačke skupine iz Zagreba, „Bad Blue Boysa“ („BBB“), skupine koja je prije svog formalnog osnivanja 1986. godine bila već dobrano ustrojena te smještena prvo na sjevernoj, a od 1984. na istočnoj tribini. ${ }^{11}$ Istovjetan proces odvija se tada i u Beogradu, gdje su navijači Partizana i Crvene zvezde podijeljeni u niz podgrupa koje će se kasnije ujediniti u „Grobare“, odnosno 1989. u „Delije“. Treba naglasiti kako nisu sve navijačke skupine iz većih gradskih sredina u sebi nosile nacionalistička obilježja. U uglavnom miješanim etničkim sredinama navijačke skupine kao što su „Red Army“, navijači Veleža iz Mostara, „Horde Zla“, navijači Sarajeva, „Manijaci“, navijači sarajevskog Željezničara, „Lešinari“, navijači Borca iz Banjaluke te, primjerice, „Red Firm“, navijači novosadske Vojvodine, ponosile su se svojom projugoslavenskom orijentacijom te zazirale od nacionalizama, što će se sa zaoštravanjem krize u većini ovih slučajeva promijeniti. Bilo kako bilo, dolazi do proliferacije navijačkih skupina u zemlji, što se treba shvatiti kao ishodišna točka modernog i organiziranog oblika navijanja kojem svjedočimo i danas.

S pojavom ekstremnih navijačkih skupina koincidiraju i prvi veći navijački ekscesi, među kojima i oni s nacionalističkom notom, a koji u fokus javnosti dolaze 1985. godine. Navijačka tematika problematizira se u dnevnim i tjednim listovima, a navijači nerijetko postaju vijest za naslovnice. U arhivi SDS-a našao se tako dokument koji je te godine Republički komitet za informiranje izradio na zahtjev Izvršnog vijeća SRH, a iz njega proizlazi kako su na nekoliko nogometnih, košarkaških i hokejaških utakmica zabilježeni nacionalistički izgredi. ${ }^{12}$ Komitet za

\footnotetext{
${ }^{11}$ Kasnije će se opet vratiti na sjever.

${ }^{12}$ Hrvatski državni arhiv Zagreb (HDA), Republički sekretarijat unutrašnjih poslova Socijalističke republike Hrvatske Služba državne sigurnosti (RSUP SRH SDS), fond 1561, šifra 0/37-3, Informacija o tretiranju u javnim glasilima ekscesnih događaja na sportskim priredbama u 1985.
} 
informiranje zapaža da sportski listovi koji pišu o izgredima nisu jedinstveni u njihovoj osudi, proziva ih se za „klubaštvo“, pa čak i da „podgrijavaju atmosferu“, a spominje se i ,nestanak jugoslavenske sportske informacije“. Jedna od analiza uzroka nacionalizma na tribinama tumačila je tu pojavu kao sredstvo zarade klubova, koji pak potiču navijače na ovakvo navijanje kako bi atmosfera bila bolja, a primjećuje se i da dijele besplatne karte najžešćim navijačima. ${ }^{13}$

Ovdje se može uočiti da su klubovi tada, a što će biti pravilo i u narednim godinama, imali dvosmislen odnos prema navijačima. Naime, službeno su se ograđivali i osuđivali nacionalističko i huligansko ponašanje, no u suštini se nisu bili spremni odreći navijačke potpore, nerijetko im pružajući i financijsku naknadu za rekvizite i slično. Kao još jedan od uzroka nereda ističe se i kriza u jugoslavenskom sportu, pogotovo u nogometu, što se ponajviše ogledalo kroz brojne namještene utakmice, razne malverzacije u klubovima, loše suđenje itd. Ipak, „Komitet“" zaključuje da su nacionalistički ispadi također posljedica ekonomske te društvene krize. Ovdje svakako valja istaknuti da su republički SDS, kao i ostala republička i partijska tijela koja su problematizirala navijački nacionalizam i huliganizam, zapravo uvijek isticali uzročno-posljedičnu vezu s krizom, pozivajući usto i na ,širu društvenu akciju“, a što će, pokazalo se, ostati mrtvo slovo na papiru. Jedan od posljednjih zaključaka „Komiteta“ jest i da je riječ o manjem broju najekstremnijih koji rade nerede, a nikako o masovnoj pojavi. ${ }^{14}$

I tijekom narednih godina u SR Hrvatskoj odigravane su utakmice koje su privlačile interes SDS-a te koje su bile indikatori onoga što se može nazvati stadionskim nacionalizmom i neredima koji su postajali sve veći problem za društvo općenito.

Jedna takva bila je utakmica između Rijeke i Hajduka, odigrana u prosincu 1988, a tadašnji su je mediji čak nazivali jugoslavenskim Heyselom. ${ }^{15}$ Bitno je istaknuti da ona nije obilovala nacionalističkim ispadima, već uglavnom čisto huliganskim. ${ }^{16}$ Pripadnici riječke „Armade“ i splitske „Torcide“ sukobljavali su se s tadašnjom milicijom, međusobno se gađali pirotehnikom i kamenjem, te pokušavali srušiti ogradu koja ih je razdvajala. Policija je uspjela spriječiti direktni sukob, no nekoliko dana poslije utakmice riječki SUP u svojem izvještaju konstatira da je sve teže održavati red na ovakvim utakmicama koje usto izazivaju vrlo ozbiljne društvene posljedice, a spominje se i pojam ,ideologija stadiona“..$^{17}$

Ponovno se kritiziraju mediji, pogotovo oni koji su objavljivali tekstove koje su pisali navijači, a što se može navesti kao još jedan forum gdje se ,podgrijavala atmosfera“. Jedna od analiza načinjenih u ovo doba tvrdi da se u zadnje dvije godine (1986/1987) na zidovima u Rijeci, u kontekstu navijačke skupine „Armade“, mogu vidjeti parole poput „Tito govno, za Krista protiv komu-

${ }^{13}$ Isto.

${ }^{14}$ Isto.

${ }^{15}$ Mate Prlić, „Navijački rivalitet bez granica: Otkud sva ta mržnja? Vratimo se u 1988. godinu,““ www.dalmatinskiportal.hr, 8. 10. 2014, pristupljeno 12. 4. 2018.

${ }^{16}$ HDA, RSUP SRH SDS, 1561, 0/37-2, Incidenti na sportskim i drugim priredbama, informacija - Rijeka.

${ }^{17}$ Isto, Obavijest - podnesene krivične i prekršajne prijave protiv navijača NK Hajduk i NK Rijeka. 
nista, živio A. Pavelić, NDH“, te da je takvih natpisa „,bezbroj“. ${ }^{18}$ Zabilježeno je da pripadnici „Armade“ i ,Torcide“ pjevaju pjesmu „Marjane, Marjane“ s kleronacionalističkim dodatkom, omalovažavajući na taj način tekovine NOB-a. ${ }^{19}$

Za pojavu i analizu stadionskog nacionalizma posebno je zanimljiva utakmica Dinama i Hajduka iz travnja 1989. godine, gdje su zabilježene sada već masovne pojave nacionalizma i, kako su to analitičari SDS-a i SUP-a zabilježili, ,kleronacionalizma“. Navijači Dinama i Hajduka, koji su tada bili u savezništvu, izvikivali su parole: „Mrzim Partizan“, „Svima nama Slobo k.... pušio“, „Hajduk i Dinamo dva su kluba bratska, njima se ponosi čitava Hrvatska“, a nakon utakmice: „Stipe Šuvar", „Idite na Kosovo“, „Ne damo vam Hrvatsku“. ${ }^{20}$ Zagrebački SUP u izvještaju poslanom republičkom SDS-u zaključuje: „Ukoliko se koordinirano, planski i organiziranom akcijom subjektivnih snaga ne presiječe ovaj negativni trend, u bliskoj se budućnosti možemo, povodom značajnijih sportskih manifestacija, suočiti s težim oblicima narušavanja javnog reda i mira u gradu Zagrebu. ‘21

$\mathrm{U}$ tim trenucima jugoslavenska kriza bila je na vrhuncu, a nacionalizam se probio kao sadržaj u partijskom diskursu. Nakon što je preuzeo rukovodstvo Saveza Komunista Srbije (SKS) te u frakcijskoj borbi na Osmoj sjednici CK SKS $(1987)^{22}$ de facto isključio iz političkog života glavnog oponenta Ivana Stambolića, Miloševićeva politika će poprimiti izraziti nacionalni karakter. Do trenutka kad je republički SDS SRH započinjao nove operativne akcije vezane uz problem navijača „Antibirokratska revolucija“ bila je suštinski završena te je bilo sve manje načina da se rješenje za krizu u državi nađe unutar same Partije. Ipak, sustav je još uvijek postojao i koliko toliko išao utabanim putem, o čemu i govori operacija SDS-a SR Hrvatske nazvana „Stadion“ (Operativno istraživanje Stadion).

\section{„Operacija Stadion““}

U travnju 1989. godine SDS RSUP-a SRH pokrenuo je akciju čiji je glavni cilj bio suzbijanje stadionskog nacionalizma. Dva dana prije pokretanja akcije održan je radni sastanak četiriju centara SDS-a (Zagreb, Split, Rijeka, Osijek) na kojem je trebalo utvrditi plan za, partijskim rječnikom sročeno, ,,poduzimanje konkretnih mjera prema inicijatorima, organizatorima i nosiocima neprijateljskih eksponiranja navijača“" ${ }^{23}$ Problematika koju je istraživanje obuhvaćalo bio je unutrašnji neprijatelj, odnosno nacionalizam. ${ }^{24}, \mathrm{U}$ cilju svestranog sagledavanja i ocjene pojava javnog nacionalističkog i kleronacionalističkog istupanja i sukobljavanja

\footnotetext{
${ }^{18}$ Isto, Informacija Darko Brnčić.

${ }^{19}$ Isto.

${ }^{20}$ Isto, 0/37-3, Informacija o zbivanjima vezanim za nogometnu utakmicu odigranu 2. travnja 1989. godine između nogometnih klubova Dinamo i Hajduk.

${ }^{21}$ Isto.

${ }^{22}$ Momčilo Pavlović, Dejan Jović, Vladimir Petrović, ur., Slobodan Milošević, Put ka vlasti. Osma sednica CK SKS, uzroci, tok i posledice (Beograd-Stirling: Institut za savremenu istoriju-Centar za proučavanje evropskog susedstva, 2008); Kosta Nikolić, „Smenjivanje Ivana Stambolića sa funkcije predsednika Predsedništva SR Srbije 1987“, Istorija 20. veka, br. 1, (2016), 159-177.

${ }^{23}$ HDA, RSUP SRH SDS, 1561, 0/37-2, Dokument 1-220, Radni dogovor.

${ }^{24}$ Isto, Dokument 1-1757, Zavođenje operativnog istraživanja Stadion.
} 
pojedinaca i grupa na sportskim manifestacijama koje postaju sve složeniji sigurnosni problem i van ovih manifestacija, kao i radi produbljivanja saznanja odnosno potvrde ili odbacivanja pretpostavke o uzrocima i karakteru navedenih oblika neprijateljskih djelatnosti, predlaže se zavođenje operativnog istraživanja Stadion. ${ }^{\text {‘25 }}$

Akcija se provodila u suradnji sa Službom javne sigurnosti, a spomenuti centri trebali su republičkom SDS-u dostaviti sva dotadašnja saznanja na temelju kojih se trebao sastaviti zajednički dosje, ali i pomoćni dosje pojedinaca koji izazivaju ispade. Također, centri su trebali opisati mjesta i način na koji su se ispadi događali i, naravno, otkriti tko su ,kolovođe“. U opsegu zadatka bilo je i prikupljanje fotografija, ali i bilježenje kafića gdje su se izgrednici okupljali, a mjere koje je valjalo poduzimati bile su pretresi, informativni razgovori, sprječavanje najekstremnijima da prisustvuju utakmicama, racije, te, naravno, održavanje radnih sastanaka sa Službom javne sigurnosti (SJS). ${ }^{26}$

Prvi izazov nakon pokretanja akcije bila je utakmica Dinamo-Crvena zvezda 21. svibnja 1989. godine. Odmah je vidljivo koje će se opsežne mjere osiguranja poduzimati u slučaju utakmica visokog rizika. ${ }^{27}$ SDS je uoči ove koristio i privremenu mjeru, odnosno tajnu kontrolu telefonskih razgovora (TKTR), prisluškujući neke od vođa navijača Dinama, u želji da saznaju kako se nabavlja i unosi pirotehnika na stadion. ${ }^{28}$ Dio vođa utakmicu je proveo u policijskoj stanici. Također, Gradski sekretarijat unutrašnjih poslova (GSUP) je još šest dana prije utakmice imao sastanak s upravom Dinama te napravio plan osiguranja, a jedan od glavnih ciljeva bilo je odvajanje suparničkih navijača, pa su svi navijači Dinama koji su imali istaknuta navijačka obilježja usmjereni na sjevernu tribinu, dok su navijači Crvene zvezde, kojih je bilo oko 2.500 , bili na jugu. ${ }^{29}$ Dio istočne tribine stadiona na Maksimiru bio je prazan i u funkciji kordona. Na utakmici koja je završila rezultatom 1-0 za Dinamo zabilježeno je nacionalističko skandiranje, provociranje i vrijeđanje. ${ }^{30}$ Tako su se mogle čuti parole „Stipe Šuvar“, „Iz Hrvatske Dinamo“, „Mi Hrvati“, „Sveti Sava-pederčina“, „Gdje si sada vojvodo“, dok su na te uvrede navijači Crvene zvezde uzvraćali: „Srbija, Srbija“, „Slobo Srbine, Srbija je uz tebe“, „Jugoslavija, Jugoslavija“, Oj, Marjane tebe ću j..... ja i Šuvara“. 31

U jednom dokumentu SDS-a, datiranom 27. travnja 1989, koji analizira zaključke ,informativnog“" razgovora s jednim tadašnjim navijačem Dinama zapisano je: „Na stadionu vodja obično započne pjesmu ili otpjeva strofu, dok navijači za njim ponavljaju. Tako pjevaju „Bad Blue Boys“, „Bog i konjica“, „Neka živi Dinamo i majka Hrvatska“, „Slobodane, Slobo, majmune sa grane, evo ide Stipe Šuvar, nosi ti banane“, „Marjane, Marjane“, sa iskrivljenim sadržajem gdje se ubacuju ime Isusovo i živjela Hrvatska, što obično pjevaju nacionalisti. ${ }^{\text {"32 }}$ Ako se

\footnotetext{
${ }^{25}$ Isto.

${ }^{26}$ Isto.

${ }^{27}$ Isto, 0/37-3, Sigurnosna procjena za dan 21. 05. 1989.

${ }^{28}$ Isto, 0/37-2, Dokument 1-1757/3.

${ }^{29}$ Isto, 0/37-3, Sigurnosna procjena za dan 21.05. 1989.

${ }^{30}$ Isto, Dokument 01/1 - str. pov. 91/89.

${ }^{31}$ Isto, Dokument 1-1757/3.

${ }^{32}$ Isto, 0/37-6, Službena zabilješka Samir Redžić.
} 
ovaj i ostali dokumenti malo pažljivije promotre, može se zaključiti kako je i sam SDS bio slabo upoznat s novim fenomenom navijačkih grupa i nastajuće subkulture. Iz današnje perspektive, pomalo smiješno, analitičari SDS-a vrlo nespretno opisuju rituale navijanja, strukturu navijačke hijerarhije i slično. Neki od analitičara slabi su u poznavanju engleskog jezika, pa se onda provlače razne greške. $\mathrm{Na}$ primjer, legendarna navijačka jakna „Spitfire“ u dokumentima se identificira kao „Sped faer“, ali ono što je zaključeno jest da su svi koji imaju te jakne navijači. ${ }^{33}$

U početnoj fazi akcije SDS je dolazio do raznih saznanja, pa je tako primijećena pomirba „Armade“ $\mathrm{i}$,Torcide“ na utakmici 30. svibnja te godine, ${ }^{34}$ a zanimljivo je i da Služba zamjećuje da se među navijačima proširio novi hit, pjesma „Ruža hrvatska“ od grupe Prljavo kazalište, čije su koncerte pohodili navijači. ${ }^{35}$ Kako je SDS zajedno sa SUP-om pratio četiri najveće navijačke skupine u SR Hrvatskoj, tj. u četiri velika centra, u fokus dolaze i navijači NK Osijeka, „Kohorta“. Valja naglasiti i da Osijekovi navijači prate političkonavijačke trendove kao što je bio slučaj u Zagrebu, Splitu i Rijeci. Na utakmici protiv Dinama u rujnu iste godine „BBB“ $\mathrm{i}$, ,Kohorta“ zajedno su navijali uzvikujući parole „Ovo je Hrvatska“, a na utakmici protiv Hajduka u studenom iste godine zajedno s ,Torcidom“ pjevana je pjesma „Ustani bane“ i izvikivana parola „Kosovo, republika“. ${ }^{6}$ Utakmica Osijeka i Crvene zvezde, 4. ožujka 1990. godine, također je obilovala nacionalističkim parolama. Navijači Osijeka su prema zapisu tamošnjeg SDS-a vikali „,Srbe na vrbe“, „Slobo Srbine, čakija ti ne gine“, „U boj u boj za narod svoj“, dok su navijači Zvezde izvikivali i pjevali ,Tamo daleko“, „Srbija, Srbija“. ${ }^{37}$ Zanimljivo je istaknuti da SDS u Osijeku u dva navrata primjećuje kako milicija ima „,tolerantan stav“ prema Kohorti. $^{38}$

Da su navijači tada već bili duboko inficirani nacionalizmom dobro kazuje utakmica Dinama i Auxerrea, odnosno jedna europska utakmica. U kolovozu 1989. godine SUP Zagreb izvještava da su navijači pjevali „Svima nama Slobo k.... pušio“, „Slobo, Srbine, čakija ti ne gine“, „U boj, za narod svoj“. 39

Posebno je zanimljiv izvještaj o utakmici odigranoj 6. rujna 1989, između Jugoslavije i Škotske u Zagrebu, inače kvalifikacijske za svjetsko prvenstvo u Italiji 1990. godine. Naime, SUP Zagreb zabilježio je da „BBB“ na sjevernoj tribini vrijeđaju igrača „svog tima“, Dragana Stojkovića Piksija, vičući „Piksi, pederu“ te „Svima nama Piksi k.... pušio“. ${ }^{40}$ Vrlo vjerojatni razlog tome jest što je Stojković simpatizirao politiku Miloševića, a u siječnju te godine beogradski Tempo objavio

\footnotetext{
${ }^{33}$ Isto.

${ }^{34}$ Isto, 0/37-3, Dokument 04-795/9 HA.

${ }^{35}$ Isto, 0/37-2, Informacija broj 229.; isto, 0/37-3, Dokument 04-795/15 HA; isto, 0/37-2, Dokument sp. 36/12.

${ }^{36}$ Isto, 0/37-3, Informacija broj 579; Isto, Informacija o ponašanju osječke Kohorte i splitske Torcide na nogometnoj utakmici Osijek - Hajduk dana 5. 11. 1989. godine.

${ }^{37}$ Isto, Zapažanja o događajima povodom utakmice NK Osijek i FK Crvena Zvezda.

${ }^{38}$ Isto, Informacija broj 579; Isto, Zapažanja o događajima povodom utakmice NK Osijek i FK Crvena Zvezda.

${ }^{39}$ Isto, Dokument 02/6-12798/89.

${ }^{40}$ Isto, Dokument 1703/16.
} 
je naslovnicu s popularnim Piksijem i njegovom izjavom: „Navijam za Slobodana Miloševića“. ${ }^{41}$ Osim toga, umjesto jugoslavenske nacionalne himne „BBB“ su pjevali „Lijepa naša“, što je, međutim, ostatak gledatelja izviždao, pa je utakmica nacionalne vrste ipak odskakala od uobičajenog navijačkog arsenala u jugoligi. ${ }^{42}$

Nekoliko dana kasnije, 9. rujna, u Splitu se igrala utakmica između Hajduka i Crvene zvezde. Jugoslavenska kriza se produbljivala, posebice nakon završetka „Antibirokratske revolucije“, ali i nakon govora na Gazimestanu u ljeto 1989. godine. Također, refleksije događanja u Srbiji osjetile se su i među hrvatskim Srbima, posebno na području sjeverne Dalmacije, Like, Korduna i Banije. Organizirana je proslava 600. godišnjice Kosovske bitke u selu Kosovo kod Knina, što je posebno iritiralo navijače Hajduka, i one iz Splita, i one s okolnih područja. SDS je sakupljao informacije iz redova „Torcide“ iz čega je zaključeno da bi utakmica mogla biti iskorištena za izazivanje nereda i iskazivanje nezadovoljstva političkom situacijom: ,,...] jer smo imali saznanja da su pripadnici „Torcide“ radi stvaranja „paklene atmosfere“, osigurali velik broj raznih vrsta pirotehničkih sredstava, a uvježbavali su i, do sada već poznat repertoar pjesama neprijateljskog sadržaja, slogana i raznih skandiranja““. ${ }^{43}$

SDS je imao točna imena ljudi koji su organizatori svih aktivnosti „Torcide“ za ovu utakmicu te vrlo detaljne izvještaje o planovima, što daje naznačiti da je Služba bila jako dobro infiltrirana u ovu navijačku skupinu. Tako su ,izvori“ javljali za razne planove, od toga da se planira spaliti velika srpska zastava (s četiri S), koji su sami sašili, do paljenja „bengalki“. SDS je imao informacije i da je trebalo doći oko 200 navijača Crvene zvezde potpomognutih simpatizerima kluba iz Knina, na što je „Torcida“ pozvala „BBB“. Zapisano je da je do sukoba došlo već na kolodvoru gdje su se od strane navijača Crvene zvezde čule parole: „Mi smo delije“, „Delije, delije, ajmo svi u glas, Slobo Milošević je uz nas“, „Slobo Srbine, Srbija je uz tebe“ itd. Prema tumačenju SDS-a „do erupcije nacionalističkog navijanja“ nije došlo, i to navodno zbog apela kluba, ali i straha od ,mjera“ Službe javne sigurnosti, kao i zbog činjenice da su organi SUP-a uhapsili (,skupili“") glavninu navijača Crvene zvezde, uključujući i ,vođu“ navijača Vladimira Vojvodića, zvanog Vojvoda. Ipak, navijači su izmjenjivali česte parole i pjesme za to doba: „Lijepa naša“, „Marjane, Marjane“, „Ružo Hrvatska“ („Torcida“), dok su „Delije“ pjevali „Đurđevdan zeleni“, „Mi smo delije“. Na povike „Torcide“ „Mi Hrvati“, „Delije“ su uzvraćali „Što se nama žalite“. Bilanca utakmice je bila 58 privedenih osoba, 23 su zadržane, protiv 13 su podnesene prekršajne prijave, a pet prijava ticalo se vrijeđanja patriotskih i nacionalnih osjećaja ljudi. ${ }^{44}$

Nedugo nakon ovih događaja SDS SRH načinio je rezime dosadašnjih saznanja iz akcije „Stadion“. Identificirani su glavni lideri četiri navijačke grupe u Hrvatskoj („BBB“, „Torcida“, „Armada“ i „Kohorta“), analizirani su njihovi

\footnotetext{
${ }^{41}$ Više o potpori Stojkovića Miloševiću vidi u: R. Mills, $n$. d., 188-189.

42 HDA, RSUP SRH SDS, 1561, 0/37-3, Dokument 1703/16.

${ }^{43}$ Isto, 0/37-2, Aktivnosti pripadnika tzv. Torcide povodom nogometne utakmice između NK Hajduk i FK Crvena Zvezda u Splitu.

${ }^{44}$ Isto.
} 
socijalni statusi, kao i „motivi“ za nacionalističke istupe. Zaključeno je da su navijači većinom stariji maloljetnici ili mlađi punoljetnici, dijelom ruralnog porijekla, slabije plaćenih poslova te agresivni prema pripadnicima milicije. ${ }^{45}$

U dokumentu se navodi i sljedeći zaključak koji je po mnogo čemu indikativan i koji, iako pisan ,udbaškim“ birokratskim rječnikom, govori o uzrocima sve većeg nacionalizma na stadionima (ali i u državi): „Dosadašnje analize također ukazuju da korijeni navijačkog huliganizma, koji kasnije prerasta i u kompleksne incidente bilo koje vrste, izrastaju iz globalnih društvenih uvjeta, kao što je sadašnja društveno-ekonomska i politička kriza, koja sve veći broj pripadnika mlade generacije dovodi u stanje frustriranosti, što se zatim vidljivo manifestira kroz njihovo ponašanje na sportskim priredbama ili u vezi s ovim priredbama."46

Prema tome, jugoslavenska kriza generira ovako ponašanje navijača. Samo što je „stanje frustriranosti“ zahvatilo ne samo mlade generacije već i čitavo društvo. Jedan drugi prilog SDS-a od 12. veljače 1990, u trenu kad je raspad bio u terminalnoj fazi, notira ono očito, tj. sugerira da bi krajnje posljedice mogle biti itekako problematične: „Prema raspoloživim saznanjima Službe, navedene pojave sa sličnim, pa i identičnim karakteristikama, prisutne su na celom području zemlje, gde klupska pripadnost dobija sve više isključivo nacionalna opredeljenja simpatizera, što kroz nacionalistička istupanja navijača i ekscesno ponašanje na stadionima, sasvim izvesno, preti da preraste $\mathrm{u}$ međunacionalnu sukobljenost $\mathrm{s}$ mogućim težim bezbednosnim i političkim posledicama. ${ }^{\text {‘47 }}$

\section{Krah komunizma - početak višestranačja u Jugoslaviji}

Politička kriza u Jugoslaviji nije se razrješavala već se svakim mjesecom zaoštravala. Rad saveznih institucija postajao je sve teži, kao i prostor za bilo kakav konsenzus. Ne smije se zaboraviti ni svjetski kontekst koji se itekako ticao Jugoslavije. Međunarodni komunistički pokret bio je pred krahom. Faktičkim sovjetskim povlačenjem iz Istočne Europe komunizam se počeo raspadati. Pad Berlinskog zida u studenome 1989. godine bio je ne samo važan simbolički trenutak nego i signal dalekosežnih promjena koje će se ticati i Jugoslavije. Naime, kako se jugoslavenska kriza odvijala unutar komunističkog sistema, a sami jugoslavenski komunisti nisu nalazili adekvatna rješenja, pojedina republička rukovodstva počela su zastupati izrazito oprečna viđenja budućnosti i federacije i odnosa u njoj. Tako su se počele otvarati pozicije za izvanpartijske političke opcije, posebice u Sloveniji i Hrvatskoj. Savez komunista Hrvatske na svom 11. kongresu u prosincu donio je odluku koja je de facto legalizirala višestranački sustav u SR Hrvatskoj. Usporedo s tim osnivane su nove političke stranke koje su se pripremale za izbore koji su se trebali održati 22. i 23. travnja (prvi krug) i 6. i 7. svibnja (drugi krug). Na političku scenu stupale su nove snage, od kojih prvenstveno treba istaknuti Hrvatsku demokratsku zajednicu (HDZ) pod liderstvom Franje Tuđmana, stranku izrazitog nacionalnog predznaka koja je na kraju pobi-

\footnotetext{
${ }^{45}$ Isto, 0/37-3, Dokument I-1757/15.

${ }^{46}$ Isto.

${ }^{47}$ Isto.
} 
jedila te preuzela vlast u svibnju 1990. godine. Nacionalna politika HDZ-a dobivala je sve više simpatizera iz brojnih razloga, a za konkretnu temu ovog članka važno je naglasiti da je program HDZ-a u velikom dijelu biračkog tijela prepoznavan kao adekvatan odgovor politici Slobodana Miloševića. Na koncu, i trendovi nacionalizma, kao što se vidi, išli su HDZ-u u prilog. ${ }^{48}$

Baš zato, utakmica između Hajduka i Dinama bila je indikator ovih dinamika. Utakmica je održana mjesec dana prije prvog kruga višestranačkih izbora u zemlji. Ovo je vrijeme savezništva navijača Dinama i Hajduka, pa je takvo ozračje zajedništva vladalo i na utakmici. SDS je očekivao oko 2.000 navijača Dinama, mahom simpatizera HDZ-a, koji će donijeti transparente sa šahovnicama te bi trebali uzvikivati ime Franje Tuđmana. Koliko su informacije SDS-a bile varljive govori podatak da je Služba imala informacije kako će jedna grupa navijača izvikivati ime Franje Tuđmana, jedna ime Savke Dapčević Kučar, a jedna Ivice Račana. ${ }^{49}$ Utakmica je na kraju završila pobjedom Dinama $3: 2$.

\section{Mit Maksimira - Dinamo protiv Crvene zvezde 1990.}

U nedjelju 13. svibnja 1990. godine u Maksimiru se trebala odigrati u rezultatskom smislu prilično nebitna utakmica između Dinama i Crvene zvezde, no zbog prethodno opisane političke klime, jedna od onih koje spadaju u kategoriju visokorizičnih. Baš u razdoblju prije izbora i nakon njih količina dokumenata iz akcije „Stadion“ nešto je rjeđa, a je li tome tako zbog otežanog rada republičkih institucija u to vrijeme, ili zbog nečega drugog, ostaje za nagađati. Vezano za ovu utakmicu, jedino na što nailazimo jesu izvješća GSUP-a Zagreb o operativnim dežurstvima, koja u najvećoj mjeri sadrže popise privedenih prije, za vrijeme i nakon utakmice. ${ }^{50}$ Niti jedan drugi izvještaj vezan uz određenu utakmicu nije ovako štur. Na ovom mjestu nećemo ulaziti u samu kronologiju događaja, koja je manje-više općepoznata, već treba istaknuti ono što se uglavnom uzima kao činjenica, pa čak i u izvještajima ondašnjih medija, koji su u velikoj mjeri o ovoj utakmici izvještavali kao da se radi o ratnim zbivanjima. ${ }^{51}$

Kao što je rečeno, za svaku visokorizičnu utakmicu postojale su opsežne mjere i razrađeni planovi osiguranja koje je policija provodila uz asistenciju SDS-a. Uslijed toga, na svim prethodno opisanim utakmicama spriječeni su potencijalno veći neredi. I na onoj godinu dana ranije u Maksimiru između istih protivnika i, primjerice, na onoj utakmici u Splitu između Hajduka i Crvene zvezde. Sve su te mjere 13. svibnja zakazale, odnosno dobar dio njih nije bio proveden. Policija je uočavala da neredi na južnoj tribini, gdje su bile smještene

48 Vidi: Zdenko Radelić, Hrvatska u Jugoslaviji 1945. - 1991. Od zajedništva do razlaza (Zagreb: Školska knjiga, 2006), 579-589; Davor Marijan, Hrvatska 1989.-1992. - Rađanje države (Zagreb: Hrvatski institut za povijest, 2017), 263-322.

${ }^{49}$ HDA, RSUP SRH SDS, 1561, 0/37-3, Dokument 04-299/1-H.A.M.S

${ }^{50}$ Isto, Dokument 511-18-15/1-7525.

${ }^{51} \mathrm{U}$ pogledu kronologije događaja, a općenito i o značaju i problematici 13. 5, svakako treba pogledati dokumentarni film Igora Grahovca, „Nedjelja 13.“, nastalog u koprodukciji AlJazeere Balkans, B-produkcije iz Zagreba, HRT-a i RTS-a; glede medijskog izvještavanja nakon same utakmice više vidi u: R. Mills, $n$. d., 211-219. 
„Delije“, poprimaju sve veće razmjere, ali nije adekvatno i pravovremeno reagirala, nakon čega se u jednom trenu raspao cijeli sustav osiguranja. Zašto je došlo do toga ponovno ulazi u domenu pretpostavke i upravo se ovdje rađa prostor za razne „teorije zavjere“ koje manipuliraju ovim događajem i koriste ga u dnevno-političke svrhe. S jedne strane imamo viđenje da su „BBB“ htjeli izazvati prekid utakmice, kako bi dali vjetar u leđa planiranoj nacionalnoj čistki u policiji, što će reći da su bili izmanipulirani od strane izbornog pobjednika HDZ-a; s druge strane pak, postoji teza po kojoj su „Delije“ isplanirale prekid, sve u želji da novu hrvatsku vlast prokažu kao ugrožavajuću za hrvatske Srbe. ${ }^{52}$

Ono što se, međutim, previđa jest činjenica da su vjerojatno i jedna i druga skupina uistinu priželjkivale nerede, pa možda planirale i prekid, ali ne zato što su bile politički upregnute, već zato što je huliganizam sam po sebi, pogotovo ovaj s nacionalističkom notom, imao za posljedicu, i još uvijek danas ima, upravo takva ponašanja. Neredi, nacionalistička vrijeđanja i ostalo bili su sasvim uobičajeni i na prethodnim utakmicama, s velikom razlikom da su ih tada od eskalacije spriječile snage sigurnosti. Ono što valja reći jest da je osiguranje ove utakmice palo u ruke takoreći „druge ekipe“, odnosno onih koji su takav visokorizični događaj osiguravali po prvi put. ${ }^{53}$ Također, često se ona činjenica o nesrazmjernom broju Srba u nacionalnoj strukturi SRH i nacionalnom sastavu RSUP-a uzima kao dokaz, tj. kao uzrok mlake i spore reakcije policije, koja je, usput budi rečeno, bila i neadekvatno opremljena, navodno zbog pritiska javnog mnijenja. ${ }^{54}$

Unatoč tome što je HDZ najavljivao prekrajanje nacionalnog sastava $u$ RSUP-u i što su, kao i svi hrvatski Srbi, policajci bili izloženi propagandi iz Beograda, a na kraju krajeva, i što su oružane snage pobunjenih Srba dobrim dijelom nastale na postojećim strukturama RSUP-a, takva teza ponovno spada $\mathrm{u}$ domenu pretpostavke, a njezino zastupanje ponovno upada u zamku dnevne politike, zanemarujući pritom kontekst koji govori o tadašnjem institucionalnom raspadanju države. Također, događanja 13. svibnja prerasla su u svojevrsni mit, i u hrvatskoj i u srpskoj javnosti. ${ }^{55}$ Ponovno s jedne strane postoji teza o početku rata na Maksimiru, brižljivo planiranom uvodu za srpsku agresiju koja će uslijediti, dok s druge, pak, teza o planiranom razbijanju Jugoslavije, ustaškom karakteru novoizabrane vlasti koji je izbio na površinu itd. Međutim, ono što, primjerice, iz jedne perspektive možemo reći, jest da teza o početku rata na Maksimiru oslobađa političku elitu od odgovornosti za rat koji će uslijediti. Takav redukcionistički pristup u suštini implicira da su navijači bili glavni uzročnici nacionalističke erupcije, a ne politička elita. Dakako, u stvaranju mita svoju su ulogu odigrali i mediji, pogotovo ondašnjim izvještavanjem, a onda i rat koji je uistinu uslijedio. Sve spomenuto, utjecalo je na napuhnutu simboliku koja se ogledala u onom udaranju milicajca od strane

${ }^{52}$ Više vidi u: R. Mills, $n$. d., 211-219

${ }^{53}$ Više vidi u: Tomislav Birtić, Krvavo plavo (Zagreb: Znak, 1997), 33-51.

${ }^{54}$ Navodno se snagama reda prigovaralo da su za utakmice opremljeni ,kao da će ratovati s navijačima“". Isto, 47.

${ }^{55} \mathrm{Za}$ antropološki uvid u ovu temu vidi: Ivan Đorđević, ,Twenty years later: The war did (not) begin at Maksimir“" Гласник етнографског института САНУ, LX, br. 2, (2012), 201-216; Ivan Đorđević, Antropolog među navijačima (Beograd: Biblioteka XX vek, 2015); R. Mills, n. d., 219-229. 
Zvonimira Bobana i u prisutnosti Željka Ražnatovića Arkana na utakmici, koji će pet mjeseci kasnije „Delije“ uključiti u paravojnu Srpske dobrovoljačke garde. ${ }^{56}$

Jasno je, stoga, da su u tumačenju 13. svibnja svoju ulogu odigrali događaji koji su uslijedili, ponajviše rat. S druge strane, u dekonstruiranju mita ne valja otići u krajnost. Sukobi koji su se dogodili na Maksimiru uistinu su dodatno zatrovali ionako vrlo zategnute odnose Hrvata i Srba, i da je kojim slučajem došlo do direktnog sukoba „BBB“ i ,Delija“, licem u lice, možda bi se danas uistinu pričalo i pisalo o jugoslavenskom Heyselu. Također, treba istaknuti da će ovaj događaj zasigurno tek postati predmetom daljnje historiografske analize, ali je svakako vrlo značajan za kontekst ovog rada.

\section{Kup Maršala Tita u sjeni Maksimira}

U dopisu Saveznog sekretarijata unutrašnjih poslova potpisanim od saveznog sekretara Petra Gračanina ${ }^{57}$ traži se da se zbog utakmice finala kupa Maršala Tita u Beogradu, igranog 19. svibnja, posveti posebna pozornost zbog incidenata na utakmici Dinama i Crvene zvezde: „Treba imati u vidu da se ova utakmica odigrava neposredno posle nemilih događaja u Zagrebu, kao i u veoma složenoj političko-bezbednosnoj situaciji u Jugoslaviji, gdje se i sportske priredbe koriste za nacionalno podvajanje, mržnju, a koja može da preraste u sukobe sa nesagledivim posledicama“. ${ }^{58}$

Odavno u dokumentima Službe državne sigurnosti ili Sekreterijata unutrašnjih poslova više nema mistifikacije. U nastavku se na osnovu ,neproverenih“ informacija sumnja da se navijači Crvene zvezde i Partizana spremaju na veliki obračun s navijačima Hajduka, Dinama i Osijeka koji su navodno zajedno trebali doći u Beograd. ${ }^{59}$ Splitski SDS javlja kako raspolaže informacijama da je „Torcida“ itekako antagonizirana zbog događaja u Zagrebu. Radikalizacija navijača značila je, kako dojavljuje splitski SDS, naoružavanje i to ,noževima, bodežima [...] te nije isključeno da posjeduju i vatreno oružje i priručno napravljene eksplozivne naprave“. ${ }^{60}$ Knin je već bio središte nacionalizma hrvatskih Srba. SDS je ostavljao mogućnost da bi vlak koji ide iz Splita prema Zagrebu mogao biti kamenovan kod Knina i to „od strane navijača Crvene zvezde koji su bili učesnici nereda na utakmici u Zagrebu 13. 5. o.g. “61

\section{Pada zastava Jugoslavije}

Utakmica između Hajduka i Partizana igrana 26. rujna 1990. godine ostat će zapamćena po još jednom incidentu punom simbolike. Naime, u ovom je raz-

\footnotetext{
${ }^{56}$ Više o tome kako su Boban i Arkan doživjeli utakmicu vidi u: R. Mills, $n$. d., 219-229.

${ }^{57}$ Petar Gračanin - Perica (1923-2004). General JNA, sudionik NOB-a, te narodni heroj. Načelnik Generalštaba JNA tijekom 1980-ih, a od 1989. do 1992. Savezni sekretar za unutrašnje poslove SFRJ.

${ }^{58}$ HDA, RSUP SRH SDS, 1561, 0/37-3, Depeša sp. br. 10691.

${ }^{59}$ Isto.

${ }^{60}$ Isto, Dokument 04-299/2-H.A.

${ }^{61}$ Isto.
} 
doblju Hrvatska već počela razvijati vlastite institucije te izglasala promjenu Ustava i državnih simbola, a u kolovozu je počela pobuna krajiških Srba, od medija nazvana „Balvan revolucija“. Na utakmici je pak ,Torcida“ dva puta izazvala prekid zbog ubacivanja pirotehnike u teren, da bi u 73. minuti, dvije minute nakon pogotka Partizana za 2 : 0, provalila u teren, na što su se suci i igrači Partizana munjevito sklonili u svlačionice. Još za vrijeme utakmice „Torcida“ je skandirala Franji Tuđmanu, kao i „Hrvatska liga“, uz još pokoju pjesmu posvećenu tekovinama endehazije. Terenom je u tim trenucima trčalo stotinjak torcidaša, a kad je publika počela skandirati „Skinite zastavu“, upravo su to i učinili, skinuvši je s jarbola na južnom dijelu stadiona te su je potom zapalili. Otprilike 20.000 gledatelja palo je u ekstazu te počelo skandirati „Hrvatska, Hrvatska“, a naposljetku zapjevalo „A sad adio“, aludirajući na bijeg iz jugoslavenske lige i zajednice. Iako je nekoliko dana prije utakmice jedan od čelnika Nogometnog saveza Jugoslavije (NSJ) spominjao eventualni eksploziv na stadionu te su navodno pokrenute opsežne sigurnosne mjere, ${ }^{62}$ snage, odsad, MUP-a, gotovo da nisu reagirale. U dokumentima SDS-a, međutim, postoji jedan jedini o toj utakmici. Tiče se razgovora vođe riječke ,Torcide“, nad kojim je primjenjivana mjera TKTR-a, i izvjesnog Vice iz Splita: „Vice iz Splita objašnjava Vuksanu da oni u Splitu imaju podršku od Hajduka kao i od HSS koja smatra da su dobro napravili. 'Isto kao kad su 900. zagrebačka omladina zapalila mađarsku zastavu'. Vice smatra da zbog svog ponašanja ,Torcida“" neće snositi posljedice“. 63

U ožujku 1991. godine, što su datacijom zadnji dokumenti analizirani iz ovoga fonda, SFRJ je bila u zadnjoj fazi raspada. Dok je tih dana Predsjedništvo SFRJ u Beogradu odlučivalo hoće li se u zemlji uvesti izvanredno stanje, Crvena zvezda je 6. ožujka 1991. igrala utakmicu protiv Dynamo Dresdena u Kupu prvaka. U organizaciji riječke Pravoslavne općine, riječke „Delije“ trebale su krenuti na put vlakom u Beograd na utakmicu. ${ }^{64}$

$\mathrm{Na}$ željezničkoj stanici napadnuti su od strane ,Armade“" $\mathrm{i}$ tom je prilikom teže ranjen jedan navijač Crvene zvezde. Nakon tuče većina je otputovala za Beograd. Po organiziranju povratka u Rijeku riječke ,Delije“ su strahovale kako će ponovno doći do okršaja s ,Armadom“ te su zato stupile u kontakte sa „svojim čovjekom“, koji je preko poznanika iz jedne policijske stanice pokušavao osigurati da ih riječki MUP dočeka. Strah je bio velik jer je na putu njihov vlak kamenovan kod Vinkovaca, a navodno su im prijetili čak i pripadnici MUP-a u Slavonskom Brodu i Vinkovcima. Također, vidi se da im je beogradska policija odbila pružiti zaštitu do Rijeke. Ukoliko pak ništa ne uspije, trebalo je potražiti ,,poznanike iz riječkog kruga Srpske demokratske stranke“. ${ }^{65}$ Osim toga ,riječke Delije“ imale su veze s djelatnicima riječkog MUPa srpske nacionalnosti (poput Dušana Lavnajića) koji su im davali informacije o ,dočeku“ „Armade“. 66 Tako se stvorio krug pomoći, gdje su na riječkom kolodvoru

\footnotetext{
${ }^{62}$ R. Mills, $n . d ., 241$.

${ }^{63}$ HDA, RSUP SRH SDS, 1561, 0/37-3, Dokument sp. 7/79.

${ }^{64}$ Isto, $0 / 37-2$, Informacija broj 47.

${ }^{65}$ Isto.

${ }^{66}$ Isto.
} 
povratnicima iz Beograda trebali pomoći riječke „Delije“ koje nisu otputovale na utakmicu, kao i pripadnici riječkog SDS-a Mišo Opačić i Željko Došen. ${ }^{67}$ Ipak, cijela priča bila je nepotrebna jer ,dočeka“ nije bilo, a i MUP je bio spreman spriječiti eventualne nerede. Naime, dokumenti SDS o akciji „Stadion“ staju s ovom zabilješkom. Ionako je SDS imao ozbiljnijih izazova od navijača. Na koncu, i nacionalizam više nije bio objekt njihovog nadzora što je 1991. godine postalo vrlo jasno.

\section{Politika i navijači}

Jedan od potencijalno najvažnijih rezultata akcije „Stadion“, a i široj javnosti vrlo zanimljivo pitanje, jest ono vezano uz eventualni neposredni utjecaj politike na navijačke skupine, a onda i uz eventualno manipuliranje navijačkim ponašanjem. U susjednoj Srbiji ta je veza ponešto jasnija, što je s obzirom na tamošnju liberalniju društveno-političku klimu u 1980-ima, možda i razumljivo. Naime, izvjesni dio „Delija“ ispočetka je bio privučen politikom Vuka Draškovića i Srpskog pokreta obnove, dio njih radio je za tu organizaciju, a dio je privukla politika Vojislava Šešelja i Srpske radikalne stranke, koji je također od navijača htio stvoriti politički kapital. Tek se kasnije „Delije“ sve više približavaju Miloševićevoj liniji, koju je, uostalom, Željko Ražnatović Arkan trebao kanalizirati i odvratiti od političkih protivnika. ${ }^{68}$ U Hrvatskoj je ta veza manje jasna. Političke stranke počinju nicati od svibnja 1989, mjesec dana nakon pokretanja akcije „Stadion“, i ako se išta može zaključiti iz dostupnih dokumenata, onda je to da su klubovi, uvjetno rečeno, manipulirali navijačima, odnosno povremeno ih logistički i financijski podupirali (transparenti i slično), što je uglavnom bilo zbog sportskih motiva.

Brojni dokumenti iz fonda republičkog SDS-a odnose se na riječku „Armadu“. U fokus riječkog SUP-a „Armada“ dolazi 1988, a već iduće godine pronađeni su oni najekstremniji među njima, evidentirana su imena navijača, a povremeno se primjenjuje i mjera TKTR. Ta se mjera jako puno koristila u slučaju jednog od vođa „Armade“, Zorana Miletića, a stalna primjena zavedena je još u studenom 1989, ne bi li SDS mogao djelovati preventivno, stekao uvid u odnose u ,Armadi“, ali i da pokuša „otkriti pozadinu, karakter i eventualne inspiratore ovakve neprijateljske aktivnosti izvan grupe". ${ }^{69}$ Miletić je prisluškivan sve do ožujka 1991. i u prijedlogu TKTR-a uvijek se spominjalo eventualno otkrivanje političke pozadine grupe, čak i nakon smjene vlasti, kad, valja naglasiti, zbog promjene diskursa nacionalizam nije više u prvom planu SDS-a, već navijački ekstremizam. Miletić je nakon smjene vlasti počeo raditi u redarskoj službi HDZ-a i SDS je nerijetko zbog toga pravdao prisluškivanje. „Gore iznesena saznanja uklapaju se djelomično u naša predviđanja da riječka Armada može biti izmanipulirana u političke svrhe. U ovom slučaju, ono može imati i ozbiljnije posljedice zbog toga što rukovodstvo riječkog odbora HDZ-a kontaktira najekstremnije i organizaciono najsposobnije rukovodioce Armade“. ${ }^{70}$

\footnotetext{
${ }^{67}$ Isto.

${ }^{68}$ Više o vezama „Delija“ sa spomenutim političarima vidi u: R. Mills, $n$. $d .$, 187-188.

${ }^{69}$ HDA, RSUP SRH SDS, 1561, 0/37-2, Dokument sp. 10/324.

${ }^{70}$ Isto, Dokument sp. 5/20.
} 
Ispostavilo se, međutim, da Miletić nije imao nikakve ideološke motive za rad u HDZ-u, već čisto egzistencijalne, a bliski kontakti s HDZ-om nisu utjecali na ponašanje ,Armade“، ${ }^{71}$ Sam za sebe je tvrdio da nema nacionalnih predrasuda, a još jedan motiv za prisluškivanje bilo je i to što je od siječnja do ožujka 1991. intenzivno komunicirao s jednim članom ,Armade“ koji je surađivao s riječkom ogrankom Srpske demokratske stranke, tj. pružao im je ,stanovite informacije o oružju, za što dobiva adekvatnu financijsku naknadu“ ${ }^{72}$ Više od toga, međutim, ne saznajemo.

Interesantno je također što su republički SDS, centar SDS Zagreb te GSUP Zagreb u trenutku pokretanja akcije „Stadion“ vrlo slabo upoznati s djelovanjem i ustrojem „BBB“, pogotovo kad se uzme u obzir da je grupa dotad već imala veći „dosje“ koji se ticao nacionalizma i huliganizma. U jednom izvještaju koji je GSUP izradio početkom travnja stoji sljedeće: „Činjenica je da se do sada u GSUP-u nitko nije bavio ovom grupacijom maloljetnih osoba ekstremno nastrojenih kroz grupaciju BBB““ 73 Dakako, „BBB“ nisu bili samo maloljetnici i dio vođa bio je upravo punoljetan, pa je uistinu nejasno što u tom početnom periodu dolaze sasvim šturi, a ponekad i krivi podaci o njima. To će se brzo promijeniti jer se od onih 1.000 dokumenata otprilike petina njih odnosi na informativne razgovore koji su po pokretanju akcije obavljeni s pripadnicima „BBB“.

Pojedini autori, a vidimo i dijelovi javnosti u Srbiji, uzimaju kao gotovo činjenicu da je između „BBB“ $\mathrm{i}$ HDZ-a postojala svojevrsna suradnja. ${ }^{74} \mathrm{U}$ jednom dokumentu nastalom u listopadu 1990, povodom utakmice između Dinama i Atalante, u sklopu Kupa UEFA-a, prisluškujući sad već novu generaciju vođa, SDS je došao do sljedećih saznanja: „Bruno je Kovača upoznao da je razgovarao s neidentificiranim Tomicom iz HDZ-a koji ih je pokušao umiriti i pridobiti te obećao prostorije BBB. Bruno je navodno odbio ovu ponudu, navodeći da BBB ne žele biti podružnica HDZa jer nisu svi u HDZ-u. Na kraju razgovora složili su se da BBB ne trebaju pristupiti nikome pa ni novoosnovanom Sokolu jer žele isključivo biti navijači Dinama.“75

Ipak, ova dvojica složili su se da treba otići na već dogovoreni sastanak s HDZ-om te zaključili da s njima trebaju biti još trojica navijača iz samog vrha. ${ }^{76}$ Ono što se misli pod prostorijama „BBB“ jesu prostorije za fan klub, što im je ranije te godine obećano da bi klub na kraju prostorije ustupio nekom trećem, zbog čega su „BBB“ zaratili s upravom. Osim ovog, u dokumentima nema više nikakvog spomena o eventualnim kontaktima, iako valja napomenuti da se od studenog 1989. do listopada 1990. dokumenti o „BBB“، pojavljuju samo u fragmentima. Naravno, nije nikakva tajna da su oni otvoreno podupirali HDZ, imali njihove transparente, ali za temeljitiju elaboraciju ovog pitanje nužna su nova arhivska istraživanja. Također, upitno je koliko je HDZ uopće trebao utjecati na jednu grupu koja je sama po sebi imala nacionalna i nacionalistička obilježja.

\footnotetext{
${ }^{71}$ Isto, Informacija broj 29.

${ }^{72}$ Isto.

${ }^{73}$ Isto, 0/37-3, Bad Blue Boys - informacije, 6.4.1989.

74 „Prava suradnja“, bez jasnog povijesnog izvora se, primjerice, spominje u: Hrvoje Prnjak, Bad Blue Boys - prvih deset godina (Zagreb: Marjan Express, 1997), 60.

${ }^{75}$ HDA, RSUP SRH SDS, 1561, 0/37-3, Dokument 18/26.

${ }^{76}$ Isto.
} 
Od sviju grupa koje su bile zahvaćene akcijom „Stadion“ definitivno najbolje obrađena bila je ,Torcida“. „Te strukture operativno pokrivamo od 1985. godine, od kog perioda do danas raspolažemo saznanjima o njihovim profilima ličnosti, mjestima okupljanja, taktikama djelovanja, idejnoj orijentaciji, međusobnim komentarima i sl.“, stajalo je u jednoj informaciji splitskog Centra iz travnja 1989. godine. ${ }^{77}$ Zanimljivo, u njihovom slučaju nije toliko upotrebljavana mjera TKTR-a, koliko ljudi na terenu i razni izvori. ${ }^{78}$

Što se tiče utjecaja politike na djelovanje „Torcide“, ponovno sličnu stvar možemo reći kao i u dijelu o „BBB“. Dokumenti naprosto ne potvrđuju pretpostavke koje pojedini autori iznose, iako je i među „Torcidom“ postojala otvorena podrška HDZ-u. ${ }^{79}$ „Nek se čuje, nek se zna, mi smo vojska Franje Tuđmana", orilo se nerijetko sa sjeverne tribine Poljuda, ali ponovno treba uzeti u obzir da su od rujna 1989. do ožujka 1991 informacije o „Torcidi“ oskudne. Ono što se može izreći kao pretpostavka jest da su od strane HDZ-a i „BBB“ i „Torcida“ imali nekakvu logističku potporu, kao što su je dobivali od klubova, čime je politika njegovala dobre odnose s njima, pogotovo u vrijeme izbora. Teško je, primjerice, zamisliti da su „BBB“ i ,Torcida“ sami izradili transparente podrške HDZ-u koje su imali na utakmicama u tom periodu.

Također, iako to može ovisiti upravo o tome koliko je koja grupa bila obrađena, može se primijetiti kako je ekstremniji desni element bio najprisutniji u ,Torcidi“. Još 1985. godine spominje se da je tadašnji vođa bio proustaški orijentiran, a sami vrh grupe inficiran ,infantilnim idejama povezanim s ideologijom hrvatskog nacionalizma“" ${ }^{80}$ Taj se odnos snaga u vrhu tijekom godina mijenjao, no ekstremna desnica u „Torcidi“ uvijek je nalazila svoje miljenike: „U krugu istomišljenika (kako pripadnika „Torcide“, tako i inače lica s kojima dolaze u kontakt), istupaju s nacionalističkih i ustaških pozicija, i to na način što ističu svoju nacionalnu pripadnost i naciju kao superiorniju nad drugima, pozdravljaju se međusobno 'ustaškim pozdravom', afirmativno govore o Anti Paveliću, NDH i ustaškom pokretu, komentiraju potrebu izdvajanja Hrvatske i Slovenije iz sastava Jugoslavije, veličaju uspjehe kosovske iredente i inače daju podršku Albancima na Kosovu, s omalovažavanjem i mržnjom govore o srpskoj naciji, ličnosti i djelu Tita, pjevaju nacionalističke i kleronacionalističke pjesme i sl.“, stajalo je u jednom izvještaju o raznim grupacijama unutar ,,Torcide“. 81

\footnotetext{
${ }^{77}$ Isto, Informacija broj 159

${ }^{78}$ Isto.

79 „No, težnje određenih političkih činitelja da manipuliraju nekim navijačkim grupama u bivšoj Jugoslaviji tek su povremeno imale uspjeha. Nerijetko su baš navijačke grupe uspijevale instrumentalizirati političke činitelje. Primjerice, Torcida je u takvim kontaktima nedvojbeno bila ravnopravan sudionik i njezino vodstvo nije bilo sklono političkom instrumentaliziranju skupine od bilo koje političke stranke“, piše D. Lalić, iako ne ističe o kojim se točno kontaktima radilo (D. Lalić, Torcida: pogled iznutra, 208).

${ }^{80}$ HDA, RSUP SRH SDS, 1561, 0/37-3, Informacija o sigurnosnim i drugim saznanjima o djelovanju pripadnika tzv. Torcide na području GZO Split u periodu od 1.1.1985.-31.1.1989.

${ }^{81}$ Isto, Informacija broj 159.
} 
Kao indikativan podatak možemo uzeti i izborne preferencije navijača. Jedna anketa iz razdoblja netom prije izbora govorila je o 15 posto torcidaša koji bi glasali za ekstremno desne stranke, a njih petorica navelo je stanovitu Ustašku stranku. ${ }^{82}$ Upravo jedan od posljednjih dokumenata govori o čemu bi se moglo raditi. Hrvatska ustaška stranka održala je osnivačku skupštinu 10. ožujka 1991. u hotelu Marjan u Splitu, a SDS sad priča o „unutrašnjem“ i „hrvatskom ekstremizmu“. ${ }^{83}$ Skupštini je prisustvovao jedan od dugogodišnjih vođa „Torcide“ koji je privukao i ostale torcidaše, a kao i predsjednik inicijativnog odbora, zastupao je ,tezu da rješavanje problema u Hrvatskoj treba prepustiti ustašama, koji će se otvoreno sukobiti s pripadnicima srpske nacionalnosti koji žive u $\mathrm{RH}^{\text {“ }}{ }^{84}$ SDS je istaknuo još jednog torcidaša koji je „održavao stalne kontakte s hrvatskim ekstremistima u Australiji. Radovčić zastupa tezu da Hrvatskoj, osim Istre, Dalmacije i Slavonije, te hrvatskog iseljeništva, pripada i teritorija $\mathrm{BIH}$, a koju cjelinu je usporedio $\mathrm{s}$ dlanom šake i prstima, koji stisnuti predstavljaju snagu i jačinu hrvatskog naroda“ “ 85

Na kraju dokumenta stoji kako se operativno istraživanje „Stadion“ nastavlja. Ekstremno desni element, dakako, bio je prisutan i među pripadnicima „BBB“, iako u dokumentima ne postoje ovako iscrpni izvještaji kao u slučaju „Torcide“, no ponovno relevantnom možemo uzeti jednu anketu prije izbora prema kojoj bi 18 posto pripadnika „BBB“ glasalo za Hrvatsku stranku prava, a devet posto za onu ustaške orijentacije. ${ }^{86}$ Naravno, to su SDS-ove procjene. U „Armadi“ su ove orijentacije najmanje primjetne, što je s obzirom na nacionalnu ispremiješanost grupe, čega je ogledni primjerak Miletić, koji je dolazio iz miješanog braka, ali se izjašnjavao Hrvatom, razumljivo. Ipak, u siječnju 1991, upravo zahvaljujući prisluškivanju Miletića, riječki SDS saznaje da u „Armadi“ dolazi do raslojavanja po nacionalnoj liniji. ${ }^{87}$

\section{Zaključak}

Kriza u Jugoslaviji u zadnjem desetljeću njenog postojanja manifestirala se na razine načine. Politički izazovi, gospodarska kriza, kao i sve jače sile decentralizacije, gdje su republike u sve manjoj mjeri koordinirano djelovale i surađivale u saveznoj vlasti, neke su od glavnih odrednica te krize. Pojavom alternativnih politika i vizija Jugoslavije unutar Saveza komunista Jugoslavije, slabljenjem komunističke ideologije i pojavom nacionalističkih rješenja utrt je put za konačni raspad zemlje. Odnos komunizma i nacionalizma u komunističkoj ideologiji, pa onda i analiza tog međuodnosa u drugoj Jugoslaviji krupno je historiografsko pitanje. Ono je u ovom radu dotaknuto u kontekstu nogometnih

\footnotetext{
${ }^{82}$ D. Lalić, Torcida: pogled iznutra, 206.

${ }^{83}$ HDA, RSUP SRH SDS, 1561, 0/37-3, Informacija broj 16.

${ }^{84}$ Isto.

${ }^{85}$ Isto.

${ }^{86}$ Nenad Fanuko i Furio Radin, Zagrebački nogometni navijači: grupni portret s BBB u središtu (Zagreb: Institut za društvena istraživanja Sveučilišta u Zagrebu, 1991), 94.

${ }^{87}$ HDA, RSUP SRH SDS, 1561, 0/37-2, Informacija broj 4.
} 
klubova i navijanja. Ovaj rad želi naglasiti da postoje supstancijalne razlike između pojava vezanih uz stadionski nacionalizam u razdoblju prije i nakon Titove smrti. Konkretno, u samoj srži većine ,ekstremnih“ navijačkih skupina, pogotovo onih koje nastaju u drugoj polovici 20. stoljeća, nalazi se nasilje, a onda i međusobno sukobljavanje. Međutim, za razliku od većine drugih navijačkih skupina, koje se sukobljavaju zbog čisto klupskih, gradskih ili regionalnih razlika, navijačke skupine u Jugoslaviji sukobljavaju se po nacionalnoj liniji. Također, odnos i pojava nacionalizma na stadionima, fenomen je usko vezan uz krizu i raspad zemlje, kao pojava koja je zahvaćala i druge sfere društva.

Pojava modernih navijačkih skupina u Jugoslaviji zakašnjela je refleksija na pojave istih organiziranih skupina tijekom 1960-ih u Engleskoj, ali i drugim europskim zemljama. ${ }^{88}$ Ipak, zbog naravi političkog sistema u zemlji, one su se počele javljati i u trenutku kada je određeni stupanj ,liberalizacije“ zahvatio Jugoslaviju i kada sam sistem nije bio represivan na razini prijašnjih godina. Osim toga, gospodarska kriza otvarala je prostor i velikim socijalnim promjenama, i razočaranosti omladine političkim sistemom, i ideologijom, kao i perspektivama. Moglo bi se ustvrditi i da je besperspektivnost mladih u krizi Jugoslavije za odgovor svoj smisao pronašla u navijačkoj supkulturi, ali što je još važnije, a što ističe sociolog Srđan Vrcan, navijači su si zadali ,generacijsku misiju u promjeni političkog kursa“ ${ }^{89}$

U tom kontekstu, dolazi i do afirmacije navijačkih skupina u zemlji, kao i pojave nacionalizma među njima. U mnogo čemu one su bile preslika političkih odnosa u zemlji ili bar novih političkih tendencija. Zato ne čudi tako velik interes Službe sigurnosti za navijačke skupine (u ovom slučaju u Hrvatskoj) koje su u svojim akcijama od 1989, pa i ranije, do 1991. godine otvoreno nastupale s raznim spektrom nacionalističkih poruka, komplementarno, svojim antipodima u Srbiji. Sadržaj poruka (pjesma i parola) egzistirao je u rasponu od raznih, većinom ,,mekih patriotskih“ narodnih pjesma, do raznih ekstremističkih i to je više manje poznato. ${ }^{90}$ Ono što je zanimljivo u ovom kontekstu je uloga i aktivnost same Službe državne sigurnosti. Osim što se SDS suočila s jednom novom subkulturnom pojavom kao što su navijačke skupine, ona se relativno uspješno infiltrirala u njih. Naravno, u neke bolje, u neke lošije. To joj je pomoglo da, koliko uopće može, kontrolira neželjene posljedice i sukobe između navijačkih skupina, što nije uvijek išlo od ruke. Isto tako, SDS je „uspješno“ dokumentirao i koliko se moglo analizirao nacionalističke pojave na stadionima. Ali na jednak način kako ni sama zemlja nije mogla suzbiti tu ,neželjenu“ pojavu, tako i „Služba“ nije imala previše kapaciteta borbe protiv ,stadionskog nacionalizma“. S jedne strane to je postala masovna pojava na samim stadionima, a s druge strane, malo po malo, to je postajala sve jača i masovnija ideološka orijentacija u društvu. $\mathrm{Na}$ koncu, i brojne navijačke skupine analizirane u radu,

\footnotetext{
${ }^{88}$ Gary Armstrong et all., Football cultures and identities (London: Palgrave Macmillan, 1999).

${ }^{89}$ Srđan Vrcan, Sport i nasilje danas u nas (Zagreb: Naprijed, 1990), 37.

${ }^{90}$ HDA, RSUP SRH SDS, 1561, 0/37-3, Informacija o sigurnosnim i drugim saznanjima o djelovanju pripadnika tzv. Torcide na području GZO Split u periodu od 1.1.1985.-31.1.1989.
} 
više ili manje, javno su koketirale ili čak u nekim vidovima surađivale s novim nacionalnim partijama. Ono što bi SDS u ranijim desetljećima bez previše izazova učinkovito represivno suzbio, sada je mogao samo promatrati i na kraju, kako je država tonula u svoj kraj, jednostavno prestati analizirati.

\section{REFERENCE}

- Armstrong, Gary et al. Football cultures and identities. London: Palgrave Macmillan, 1999.

- Bilandžić, Dušan. Propast Jugoslavije i stvaranje moderne Hrvatske. Zagreb: AGM, 2001.

- Birtić, Tomislav. Krvavo plavo. Zagreb: vlast. nakl., 2013.

- Brentin, Dario et all. Sport in Socialist Yugoslavia. London: Routledge, 2019.

- Cukrov, Mladen. „Šezdeset pet godina obnove Hajduka na otoku Visu“. Kulturna baština, br. 9, (2009), 23-42.

- Đorđević, Ivan. Antropolog među navijačima. Beograd: Biblioteka XX vek, 2015.

- Đorđević, Ivan. „Twenty years later: The war did (not) begin at Maksimir“. Glasnik etnografskog instituta SANU, LX, br. 2, (2012), 201-216.

- Fanuko Nenad, i Furio Radin. Zagrebački nogometni navijači: grupni portret s $B B B$ u središtu. Zagreb: Institut za društvena istraživanja Sveučilišta u Zagrebu, 1991.

- Glaurdić, Josip. Vrijeme Europe - Zapadne sile i raspad Jugoslavije. Zagreb: Mate-ZŠEM, 2011.

- Kovačić, Davor. Hrvatski nogomet u doba cara, kralja, poglavnika i maršala. Zagreb: AGM - Hrvatski institut za povijest, 2019.

- Lalić, Dražen. Nogomet $i$ politika: povijest $i$ suvremenost međuodnosa u Hrvatskoj. Zagreb: Fraktura, 2018.

- Lalić, Dražen. Torcida: pogled iznutra. 2. izd. Zagreb: Profil multimedija, 2011.

- Marijan, Davor. Hrvatska 1989.-1992. - Rađanje države. Zagreb: Hrvatski institut za povijest, 2017.

- Mijatov, Nikola. „Sport u službi socijalizma: jugoslovensko iskustvo 19451953“. Doktorska disertacija, Univerzitet u Beogradu, Filozofski fakultet, Odeljenje za istoriju, 2019.

- Mills, Richard. Nogomet i politika u Jugoslaviji: sport, nacionalizam i država. Zagreb: Profil, 2019.

- Mlinarić, Ivan. „Naletjeli smo na mali povijesni ekskluziv; Hajduk je 1980. htio da se Poljud nazove po Titu“. www.telegram.hr, 26. 11. 2017, pristupljeno 19. 8. 2019.

- Nikolić, Kosta. Jugoslavija, poslednji dani (1989-1992. Knjiga prva: Svi Srbi u jednoj državi. Beograd: Službeni glasnik, 2018.

- Nikolić, Kosta. „Smenjivanje Ivana Stambolića sa funkcije predsednika Predsedništva SR Srbije 1987“. Istorija 20. veka, br. 1, (2016), 159-177.

- Pavlović, Momčilo, Dejan Jović, i Vladimir Petrović, ur. Slobodan Milošević, Put ka vlasti. Osma sednica CK SKS, uzroci, tok $i$ posledice. Beograd- 
Stirling: Institut za savremenu istoriju-Centar za proučavanje evropskog susedstva, 2008.

- Pilić, Damir. „Dan kad je umrla Jugoslavija: prije točno 25 godina prekinuta je utakmica između Hajduka i Partizana“. slobodnadalmacija.hr, 26. 9. 2015, pristupljeno 27. 4. 2018.

- Prlić, Mate. „Navijački rivalitet bez granica: Otkud sva ta mržnja? Vratimo se u 1988. godinu.“" www.dalmatinskiportal.hr, 8. 10. 2014, pristupljeno 12. 4. 2018

- Prnjak, Hrvoje. Bad Blue Boys - prvih deset godina. Zagreb: Marjan Express, 1997.

- Radelić, Zdenko. Hrvatska u Jugoslaviji 1945. - 1991. Od zajedništva do razlaza. Zagreb: Školska knjiga, 2006.

- Vrcan, Srđan. Sport i nasilje danas u nas. Zagreb: Naprijed, 1990.

MARTIN PREVIŠIĆ, PhD, Assistant professor

Faculty of Philosophy, University of Zagreb

Zagreb, Republic of Croatia

martinprevisic@gmail.com

IVAN MLINARIĆ, mag. hist.

Zagreb, Republic of Croatia

ivanmlinaric99@gmail.com

\section{STATE SECURITY SERVICE OF SR CROATIA AGAINST FOOTBALL SUPPORTERS 1989-1991}

\section{Summary}

The 1980s saw an expansion of supporter groups. Given the general crisis in the country, the soccer fans in Yugoslavia and their activities were more and more subjects of interest of the Yugoslav secret police. Based on the archival materials of the Croatian State Security Services, this work analyzes activities of the four major supporter groups in the then Socialist Republic of Croatia (Bad Blue Boys, Torcida, Armada and Kohorta) between 1989 and 1991. It looks into various aspects of monitoring and interpreting the emergence and activities of supporter groups by the secret police, with particular focus on the rise of nationalism in the context of movements throughout the country. By presenting these aspects, the work seeks to contribute to the historiographic analysis of the causes and atmosphere that led to the break-up of Yugoslavia.

KEYWORDS: Yugoslavia, Dinamo, Hajduk, State Security Service, Football supporters, Croatia 